\title{
気候モデルから得られる多数のアンサンブルデータを 用いた確率降水量の推定法
}

\author{
北野利一 ${ }^{1} \cdot$ 高橋倫也 $^{2} \cdot$ 田中茂信 ${ }^{3}$ \\ 1 正会員 博 (工) 名古屋工業大学大学院工学研究科 准教授（广 466-8555 名古屋市昭和区御器所町） \\ 2 工博＼cjkstart神戸大学 名誉教授（干 658-0022 神戸市東灘区深江南町 5 丁目 1-1） \\ 3 正会員 博（工） 京都大学 防災研究所教授（干 611-0011 宇治市五ヶ庄）
}

\begin{abstract}
降水量の観測記録を用いる場合には, 外挿は, 治水計画に必要となる極值統計解析で不可避であり, 信頼で きる推定結果を得るためには，記録長が十分でないという問題に直面する．実際のところ，現実の降水量記録 への極值理論の適用の可否が十分に確認できかったり, また, 漸近モデルの適用が不十分であると, 確率降水 量の推定にバイアスがかかることもある. 本研究では, d4PDF の出力結果を用いて, 極值の漸近理論の適用 性の確認法や，多数のアンサンブル標本から得られる推定結果のまとめる手法を提示する.
\end{abstract}

Key Words: Return Period, Degree of experience, Poisson test, Climate change, d4PDF

\section{1.はじめに}

システィーナ礼择堂天井画にて, 水工学的に注目 すべき作品が少なくとも 2 点ある。一つは「大洪水」, もう一つは「アダムの創造」である。前者は水災害 の極みであるので当然と言えるが，後者は意外に思 うかもしれない.

我々が現実世界で観測できる降水量の極值を確率 現象の 1 組の実現值であるとみなせば, 多数のアン サンブル標本で検討できる世界は, 神の世界に近い. 極值の漸近理論において，年最大值分布が極值分布 にしたがうならば， $R$ 年（例えば，100 年）最大值 分布は，位置および尺度母数は異なるが，同じ形状 母数の極值分布にしたがう。これを言換えれば，再 現期間に対する確率降水量の関係を表すクオンタイ ル曲線が同一（スケールが異なるので相似）を表し ている。このことは,「アダムの創造」を想起させる。 なぜなら，「神の上半身の筋肉構造は強調され，聖 書におけるアダムと神の相似に目に見えるかたちを 与えている」と指摘 ${ }^{1)}$ されるとおりであり，地上で 我々が入手できる観測データの世界と，神のみぞ知 り得る外挿の世界の各々の極值分布が相似形となる ことに対応しているからだ.

気候変動リスク情報創生プログラムで, 多数のア ンサンブル標本を使える状況になった。したがって, 1 組の実現值（60 年分の年最大值）に対して, その 外挿となる領域に, もう 1 組の実現值（60 年最大值 のアンサンブル）を得たことになり，たとえが大げ さであるかもしれないが, それは，まさに地上と神 の世界との相互比較ができる機会を得たと言える。

多数のアンサンブル標本が使える状況で，個々の 標本から得られる推定と, 標本の最大值のみのアン
サンブルを用いた推定の両者について, 上述した確 率降水量の相似性, すなわち, 極值統計解析による 両者の結果の一貫性を検証する手法を論じること が, 本研究の目的である。

\section{2.ノンパラメトリック法（単純法）}

本研究で例示に用いる対象データは,「地球温暖 化対策に資するアンサンブル気候予測データベース (d4PDF)」 2) の成果を用いて, 日本域 $20 \mathrm{~km}$ のダウン スケールによる出力のうち, 名古屋を含む格子（東 経 136.906, 北緯 35.071 を南西端, 東経 137.130, 北緯 35.254 を北東端とする格子内）の過去実験データ出 力值 (1951-2010 年の 60 年×50 アンサンブル標本) を用いる。なお, 本稿では, 多数のアンサンブル標 本がある場合に，極值統計法の一貫性とその限界を 論じることに主眼があるため, あえてバイアス補正 をしないままのデータを用いることを断っておく.

全てのアンサンブル標本を一括し, 日降水量の年 最大值 60 個 $\times 50$ アンサンブル標本 $=$ 総数 3000 個 を降順に並べて図示したものを図-1 に示す.この時, 割合の関係として, 30/3000 = 1/100 であることから, 総数 3000 の年最大值のうち, 上位 30 番目のデータ (順位統計量) を 100 年確率降水量 $\mu_{100}$ として推定 することを，ノンパラメトリック法（あるいは単純 法）とよぶ. この場合, $280 \mathrm{~mm}$ と推定される.

この方法は, 未知となる母数（パラメータ）を含 む極值分布を用いない点で, 単純明快かつ直接的で あるため, 政策決定者にも訴えやすいという利点が ある。また，図-1 を見ると拈り，上位 10 個程度ま ではばらつくものの, 上位 30 個前後となると, あ る傾向をもった曲線（この場合は，ほぼ直線）上に 


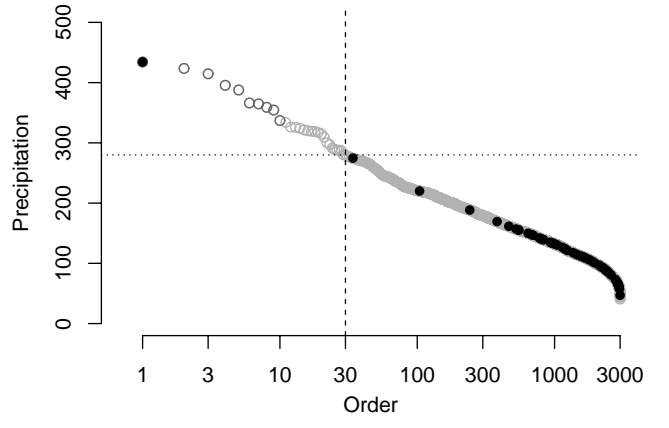

図 -1 3000 年分の年最大日降水量の順序統計量 （順位を示す横軸は対数スケール，

・印は全体の最大值を含むアンサンブルを表示）

並んでおり，ほとんど誤差が無いように見える点で も好都合である. しかし，後に示すとおり，誤差に 関しては，錯覚であることに注意すべきである.

このノンパラメトリック法で, 確率降水量の区間 推定に言及されることは少ない. 私の知る限りでは, 気候変動の研究では皆無である.この場合の区間推 定は，次のように考える。降水量に対する確率分布 は仮定していないので，降水量に関しては，順位統 計量しか用いることができない，そのため，30/3000 という割合に関して，確率分布を用いて，その変動 区間を求めるのである.すなわち, 試行数 3000 の内, 母比率 $1 / 100$ で生じるイベントの生起数 $k$ に対して,

$$
P(k)=\sum_{j=0}^{k}\left(\begin{array}{c}
3000 \\
j
\end{array}\right) 0.01^{j} 0.99^{3000-j}
$$

で表される 2 項分布を用いれば，図 -2 a) 左に示す と抢りで変動する。その範囲は, 確率 0.95 で,

$$
20 \leq k \leq 40
$$

となる. 対応する順位の降水量（の順序統計量）を 読み取り, 100 年確率降水量 $\mu_{100}$ の区間推定として,

$$
270 \mathrm{~mm} \leq \mu_{100} \leq 315 \mathrm{~mm}
$$

と求まる. 同様に，母比率 $1 / 200$ の場合も，その生 起数 $k$ は, 図 -2 a) 右に示すと打り, 確率 0.95 で, $8 \leq k \leq 22$ の範囲で変動し, 確率降水量 $\mu_{200}$ の区 間推定は, 次のとおりに得られる。

$$
300 \mathrm{~mm} \leq \mu_{200} \leq 359 \mathrm{~mm}
$$

これらの誤差量 (図-2 b) に矢印で提示) は, 図 -1 を見た時の視覚的に直感する誤差よりも，かな り大きいと感じるのではなかろうか？逆に言えば, 図-1 を単純に見る限りで, 誤差がほとんど無いよう に見える錯覚は，なぜ生じるのか？その原因は，順 位統計量の䛊差を読み取ることにある．例えば， 30 番目の順位統計量は, 29 番目より小さく, 31 番目 よりも大きい制約のため，30 番目の順位統計量がと りうる範囲はかなり限定される．そのため，30 番目 の順位統計量は微動ゆえ, 図 -1 に示す曲線／直線は, 視覚的に滑らかで, 誤差は微少であるかのような印
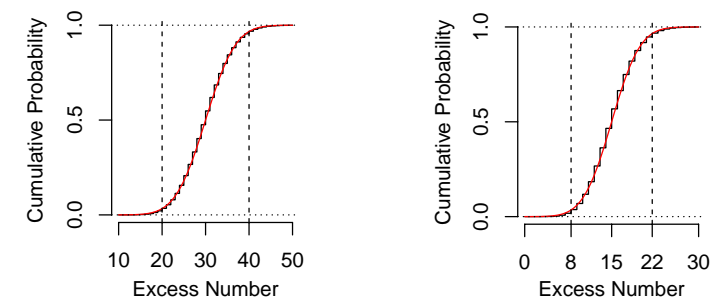

(a) 総数 3000 における超過確率に対する順位の区間推定 （超過確率 1/100 を左に，1/200 を右に表示）
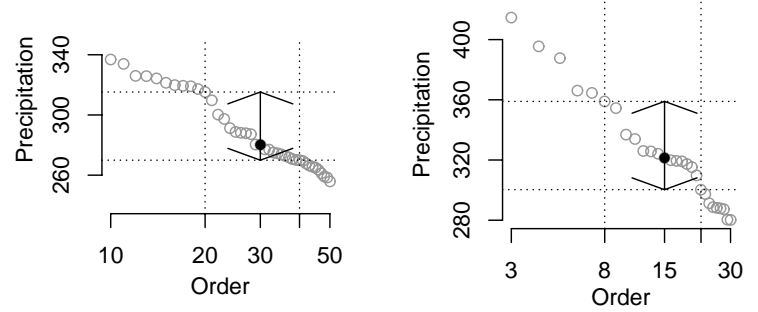

(b) 確率降水量の区間推定

（再現期間 100 年を左に，200 年を右に表示）

図-2 ノンパラメトリック法による区間推定

象を与える. しかし, 1/100 という割合の真值に対し, 実現值がちょうど30/3000 となることは, 単なる偶 然であることを強調しておく. 図-1 の・印に示す アンサンブル標本は極端な例になるけれども，割合 が 2/60 となる降水量が，30/3000 程度をとることか らも，その変動の幅が大きいことを裏付けている.

\section{60 年間のアンサンブル毎の極值解析とアンサン ブルによる 60 年最大值の極値解析の関係}

\section{(1) アンサンブル毎の極值統計解析}

1 つのアンサンブルあたり期間長 60 年の極值を 対象に, 一般的な極值統計解析 ${ }^{3)}$, 4) が可能である. 本研究では, アンサンブル標本を用いた議論を明確 にするために, 取扱うデータは年最大值のみに限り, また, 経時的トレンドを含めた検討はしない, 閾值 を超過する極值を用いるなど工夫次第では, 推定誤 差をより小さくできる分, トレンドも含めた詳細な 検討も可能な枠組みであることを断っておく.

期間最大值 y の漸近分布は, 収束する場合, 次式 で表される一般化極值分布となる。

$$
F(y)=e^{-\lambda\left(y, \boldsymbol{\theta}_{n}\right)}
$$

ここで, $\lambda\left(y, \boldsymbol{\theta}_{n}\right)$ は, 次式で表される生起率であり, 母数 $\boldsymbol{\theta}_{n}=\left\{\mu_{n}, \sigma_{n}, \xi\right\}$ が含まれる（ $n$ は期間長）.

$$
\begin{array}{cc}
\lambda\left(y, \boldsymbol{\theta}_{n}\right)=\exp \left(-\frac{y-\mu_{n}}{\sigma_{n}}\right) & (\xi=0) \\
=\left(1+\xi \frac{y-\mu_{n}}{\sigma_{n}}\right)^{-1 / \xi} & (\xi \neq 0)
\end{array}
$$

名古屋市における観測降雨量に対する極值統計解 析 ${ }^{5)}$ によれば， $\xi \neq 0$ であることを積極的に言えず, むしろ， $\xi=0$ とするのが妥当である判断できる. また, 図-1 にて, 30〜300 程度の順序統計量の変 


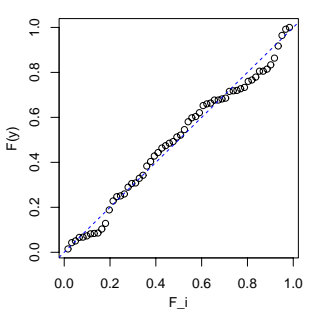

a) PP プロット

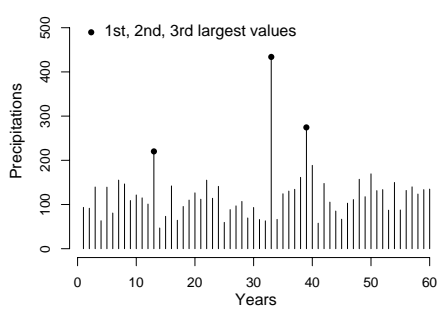

b) 年最大值の時系列

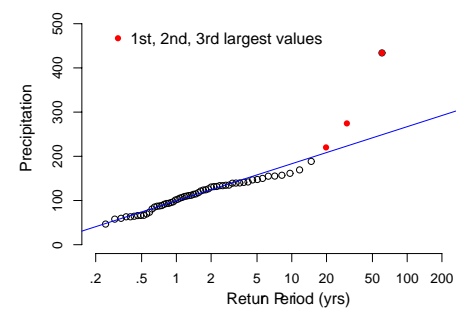

c) 再現レベルプロット

図 -3 アンサンブル標本 \#17 の 60 年分の年最大值による極值解析の結果例

動が少ないところで，順位の対数に対して降水量の 極值が直線的であることからも， $\xi=0$ となること が裏付けられる。すすおち，たかだか 100 年程度に 限られる観測期間の記録では， $\xi=0$ からのわずか な乘離を検出するためには, 情報が不足していると 言える. 以下では， $\xi=0$ と固定して検討する.

図 -3 a) は, 全体の最大值 $434 \mathrm{~mm}$ を含むアンサン ブル標本（\#17）の 60 年分（年最大值の時系列を図 -3 b) に表示）に対する母数の最尤推定值

$$
\hat{\mu}_{1}=99.4 \mathrm{~mm}, \quad \hat{\sigma}_{1}=36.4 \mathrm{~mm}
$$

を式(5)に代入して得られる累積確率に対して,

$$
F_{i}=\frac{60+1-i}{60+1}
$$

を用いて, 降順位 $i$ で割付けた確率の関係を示して おり, これが, $\mathrm{S}$ 字やJ字（その逆の形など）の傾 向が無いことを確認するものであり, 図-3c) は, 式 (6a) の生起率関数を用いて, 次式で表される再現期 間 $R$ と確率降水量 $\mu_{R}$ の関係を青線で示す.

$$
\lambda\left(\mu_{R}, \boldsymbol{\theta}_{1}\right)=\frac{1}{R}
$$

この 60 年分のアンサンブル標本が，現実のデー タであるなら, 最大值 $434 \mathrm{~mm}$ が確率降水量を示す 青線から大きく乘離することに懸念が生じる. しか し, 今回の気候モデルの数值実験で, $434 \mathrm{~mm}$ は, 3000 年分の最大值に相当しているため, 図 -3 c) の ような乘離がある場合も，それがある 60 年間に偶 然に出現したものとして, 格段の違和感は生じない.

図-4 は, 50 アンサンブル全てについて, 図-3c) と同じように年最大值を灰色でプロットした上に, 尺度母数が最大と最小をとる場合の標本 $(\# 40,45)$ を実線で結ぶとともに，ガンベル分布で推定して得 られる再現期間と確率降水量の関係を青点線で示し た（青実線は 図-3c) と同じであり, 標本 \#17 は異 なる濃さの灰色で表示した)，したがって，青点線 に見られる程度の大きな変動を伴うものであること がわかる。 なお，再現期間を 60 年とする確率降水 量の推定が, 60 年最大值の中心部にあらず，下方部 にあることにも注意されたい。これは，式(6a) およ び (5) を見るとおり,$n=60$ 年最大值のガンベル分 布 $(\xi=0)$ では, 最頻值をとる $\mu_{60}$ の累積確率は,

$$
F^{60}\left(\mu_{60}\right)=e^{-1} \approx \frac{1}{3}
$$

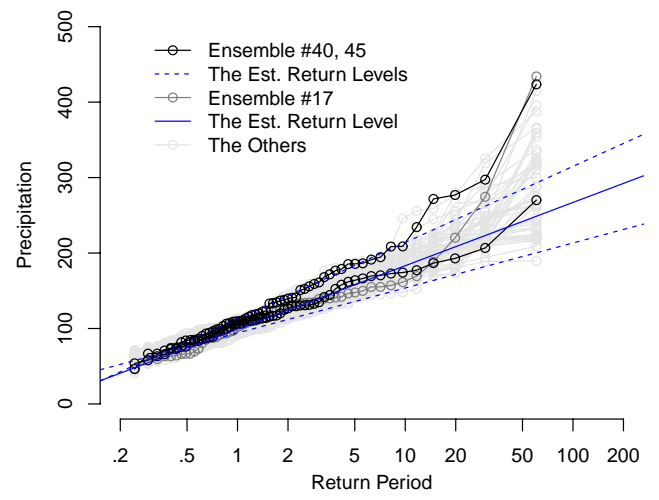

図-4 降水量と再現レベルの関係

となることから董付けられる。これを，ポアソン分 布の性質を表す Rule of Three に加え, Rule of Thirds とよんでいる ${ }^{6}$.

\section{(2) アンサンブルによる 60 年最大值の極值解析}

60 年最大值がアンサンブル数 50 あるので, 60 年 最大值分布の母数 $\boldsymbol{\theta}_{60}\left(=\left\{\mu_{60}, \sigma_{60}\right\}\right)$ を推定し, こ れを用いて得られる再現期間と再現レベルの関係を 図 -5 に示す (赤線). 極值理論の漸近理論では, 年 最大值から得られる関係と, $n$ 年最大值から得られ る関係が, 同一 (曲線) であることが示される。こ のことは, 位置と尺度の母数が, $\xi=0$ では,

$$
\mu_{n}=\mu_{1}+\sigma_{1} \log n, \quad \sigma_{n}=\sigma_{1}
$$

であり, $\mu_{n}$ が $n$ 年確率降水量となる。期間長を $m$ 倍して, $n m$ 年確率降水量は,

$$
\mu_{n m}=\mu_{n}+\sigma_{n} \log m,
$$

を表されることから， $\mu_{n}$ と $\mu_{n m}$ の両者は同一直線 として連続することがわかる $(\xi \neq 0$ の場合も類似 した関係式により, 同一曲線と連続する)。図 -5 を 見るとおり, 標本から得られる関係では, 推定䛊差 を伴うため，一致していないようにも見える．この 不一致（ズレ）が, 統計的に有意であるか否かを議 論できるだけのデータ数があるところに，d4PDFの 意義があると考える. その検討手法を次節で論じる.

アンサンブルにおける極值を, 60 年最大值のみなら ず, 上位 $r$ 番目までの極大值 $Y_{i}^{(1)} \sim Y_{i}^{(r)}(r=1$ の場合 には, 60 年最大值のみに対応）を用いて, 次式で表さ れる対数尤度の最大化により, 母数 $\boldsymbol{\theta}_{60}\left(=\left\{\mu_{60}, \sigma_{60}\right\}\right)$ を推定できる，その結果を図-6に示す，下位の極值も 


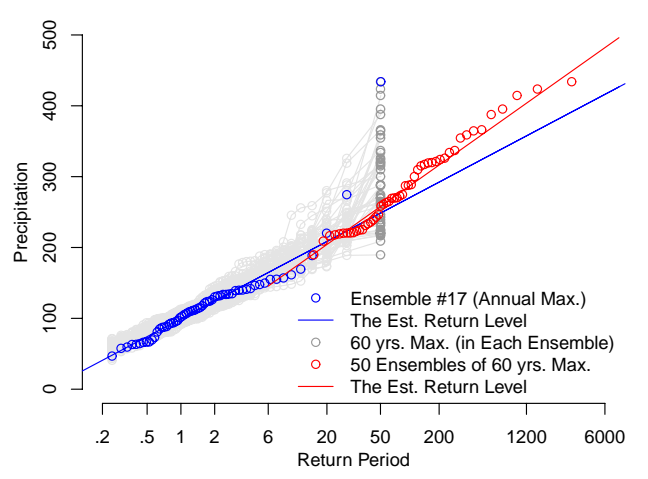

図 -5 降水量と再現レベルの 2 つの関係

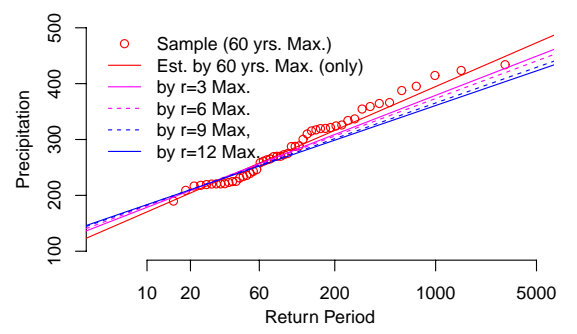

図 -6 60 年間の上位 12 番目までの極大值を用いた推定 による降水量と再現レベルの 2 つ関係

含むことにより，勾配が緩くなっていることがわかる.

$$
\begin{aligned}
\ell\left(\boldsymbol{\theta}_{60}\right)=- & \sum_{i=1}^{50}\left[\lambda\left(Y_{i}^{(r)}, \boldsymbol{\theta}_{60}\right)\right. \\
& \left.+\sum_{j=1}^{r} \log \left\{-\frac{d \lambda}{d y}\left(Y_{i}^{(j)}, \boldsymbol{\theta}_{60}\right)\right\}\right]
\end{aligned}
$$

\section{4. アンサンブル毎に得られる推定結果の統合法}

\section{(1) 得られる確率降水量の推定値の分布}

図 -7 a) は，アンサンブル標本毎に得られる確率降 水量を累積確率分布で表示したものである。これは, 推定に伴う誤差によるものであり，再現期間の延長 とともに傾きが緩くなり，誤差が大きくなることを 示している. 比較のために, 図-7b) は, アンサン ブル標本 \#17 の年最大值と 60 年最大值標本の累積 分布を示す。これらは, 推定に伴う誤差ではなく, 本来の確率変動であり，期間が 1 年および 60 年の 最大值のバラツキは同程度であり, 位置のみ異なり $\left(\mu_{60} \neq \mu_{1}\right)$, 累積分布の平行移動を示している. こ れは, すなわち, 式 (11) に記した関係 $\sigma_{60}=\sigma_{1}$ を 表し， $\xi=0$ と仮定できることを示唆する.

確率降水量は推定值であるゆえに，一般には，中 心極限定理から，その誤差が正規分布にしたがうこ とを期待する。しかし，推定すべき外挿領域では， 誤差偏差が大きく, 中心極限定理が十分に適用でき ないと予想される。再現期間 $R=1,60$ および 200 年 とする確率降水量の推定值（50 標本）のヒストグラ ムと正規確率紙（図 -8）を示すと打り，裾部の乘離 が見られ，その適合性は悪く，これを裏付けている。

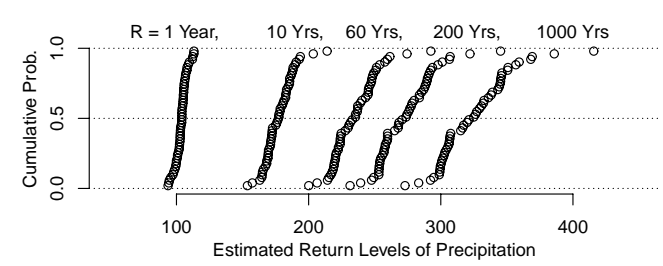

(a) 確率降水量の推定值の累積分布

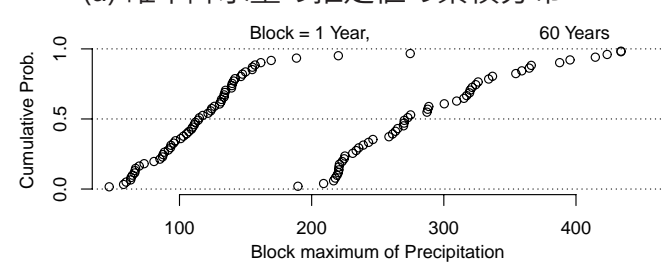

(b) 期間最大值の確率変動

図-7 推定䛊差と極值そのものの確率変動
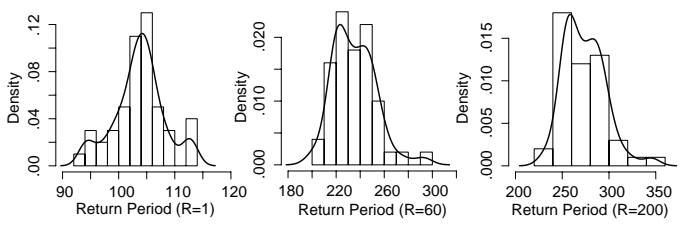

(a) ヒストグラム
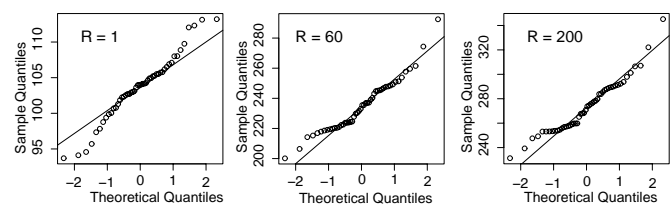

(b) 正規確率紙による表示

図-8 推定される確率降水量の誤差分布特性

\section{(2) 降水量のレベルに対する生起率の推定值の分布}

アンサンブル＃ $i$ で推定される母数 $\tilde{\theta}_{R *}(i)$ を与 えれば，式 (6) を用いて，降水量 $y$ に対する生起率 $\lambda\left(y, \tilde{\boldsymbol{\theta}}_{R *}(i)\right)$ に変換できる. 得られた生起率のヒスト グラムならびにガンマ確率紙に表示したものを図 -9 に示す。なお, 後者にプロットする際, 次式で表さ れるガンマ分布の密度関数に含まれる母数 $\beta$ および $K$ を最尤推定により求めたものを用いている.

$$
g(\lambda)=\frac{\beta^{K} \lambda^{K-1} e^{-\beta \lambda}}{\Gamma(K)}
$$

ここで，ガンマ分布を用いるのは，ポアソン分布の 母数となる生起率を確率変数として扱うため, ポア ソン分布に自然共役な分布であることによる。すな わち, ここでは, 本来的に定数である生起率を確率 変数として扱い, ベイズ統計の発想をしている.な お, 式 (5) に示した一般化極值分布の表現は, 次式 で表されるポアソン分布に, 生起数 $k=0$ として, 生起率を代入して得たものである.

$$
f(k)=\frac{\lambda^{k} e^{-\lambda}}{k !}
$$

ここで，ガンマ分布に含まれている母数 $\beta$ は，ポア ソン分布では $\beta=1$ となるので省略できる。逆に言 えば, 生起率が確率変数になると, 微調整のために 必要になる。すなわち, アンサンブル標本毎に推定 
する母数 $\tilde{\theta}_{R *}(i)$ は，予め再現期間を与える必要が あり, その結果として得られる生起率の期待值（定 数となるべき本来の生起率) を求めると,

$$
\mathrm{E}\left\{\lambda\left(\mu_{R}, \tilde{\boldsymbol{\theta}}_{R}\right)\right\}=1
$$

として, 与えた再現期間において生起率は平均 1 回 となるべきであるが，そうならない，そのための調 整の係数である．このような調整が要るのは, 分か らないものを予め分かっている必要があることに起 因するため不可欠である. したがって, 母数 $\tilde{\theta}_{R *}(i)$ を求める際に予めに与える再現期間は, 最終的な再 現期間 $R$ とは異なるので， $R *$ と記して区別する.

図 -8 に示した確率降水量の正規性の適合の悪さと 好対照に, 図-9 のガンマ分布での適合性は十分に良 いと言える。このことは，中心極限定理による誤差 の正規性を期待するよりも，極值の希少性を表すポ アソン分布の母数 (生起率) に変換した方が, その 不確実性の変動を適切に扱えることを示している.

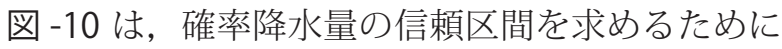
必要となる諸量の関係図である. Box の囲みがあるa) は, 降水量 $y$ を変化させて与え (横軸), 式 (14)よ り最尤法で求められる (期待) 生起率の推定值 (縦軸) を示している．また，b) は，同時に得られる形状母 数 $K$ の推定值（縦軸）を示し，c）は，その対応す る再現期間（横軸）との関係を示している．ガンマ 分布の形状母数 $K$ は, 式 (13) と (14) を比較して分 かるとおり, ポアソン分布の生起数に相当し, 個々 のアンサンブルに対する経験度（降水量 $y$ を超える

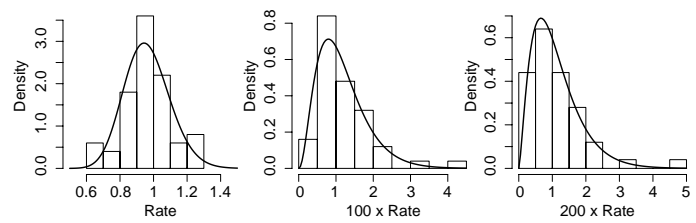

(a) ヒストグラム
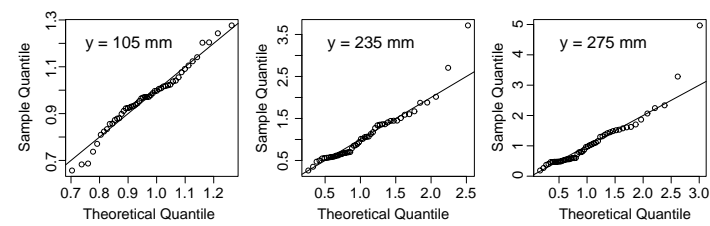

(b) ガンマ確率紙による表示

図-9＼cjkstart推定される生起率の誤差分布特性

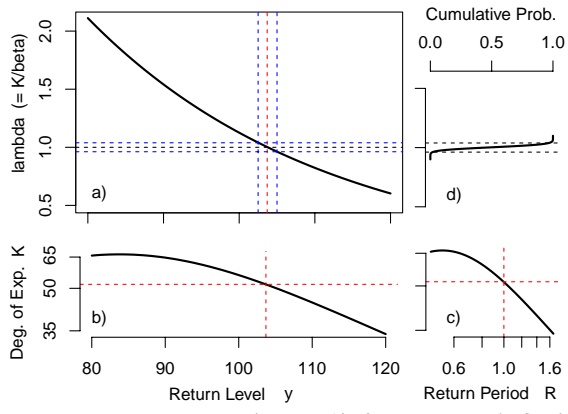

仮想的な生起数）である. $\lambda$ の肩の $K$ に -1 が付く のは, ベイズ統計として, 生起率の事前分布を

$$
g_{0}(\lambda) \propto \lambda^{-1}
$$

で与えていると解釈できる。これを元に，生起率の 区間推定を行う場合は，50 標本を包括することにな り, 形状母数（すなわち, 経験度）を $50 K$ として, 事前分布を更新した事後分布のガンマ分布を用いれ ばよい. d) は，ガンマ分布の累積確率を表し，その 端点 $(P=0.025,0.975)$ の生起率に対応する降水量 を読双取れば，確率降水量の 95\% 信頼区間を求める ことができる。これは，2，のノンパラメトリック 法により, 確率降水量の信頼区間を求める際に, 図 -2で示した手順に相当する.

\section{5. 外挿域における接続についての検定}

60 年間の標本 1 つの記録に対して, $\mu_{100}$ は外插 域にあり, また, 60 年最大值も外挿域（の淵）にあ る. 図-11 左に, 各アンサンブルから得られる 100 年確率降水量 $\mu_{100}$ の推定值（○印に灰色の信頼区 間付）と，それを包括して得られる信頼区間 A（黒 の逆矢印）を示し，これに対して，60 年最大值（50 アンサンブル分）を用いて得れる確率降水量の信頼 区間 B（青の矢印）も示している。まず確認してお きたいのは, 各標本による推定になんらかの傾向が 無いことである. また, 包括的に推定される降水量 $255 \mathrm{~mm}$ (点線) を含まない $95 \%$ 信頼区間 (灰色) が, 50 の内 2 つ(赤矢印)あることは妥当であろう. 次に, 信頼区間 A, B は互いに重複しない. また, 同様の比 較を生起率で表したものを図-11 右に表示する。こ の場合も, 両者の信頼区間は重複しないだけでなく, 前者が 100 年に平均 1 回に対して, 後者は平均 1.76 回になる.この結果, この地点での降水量の極值に 対して, 60 年間の記録から再現期間 100 年の外挿を 推定することは難しいこと（過小評価の傾向）を示 唆している，これは，図-6で 60 年間の上位 $r$ 個を 用いる解析で, 60 年最大值のみ $(r=1)$ に比して, 下位の極值を取込むと，過小評価されることからも 裏付けられる。信頼区間の算定に用いた経験度は, $K_{A}=150.8, K_{B}=46.3$ であり，極值の生起率の相

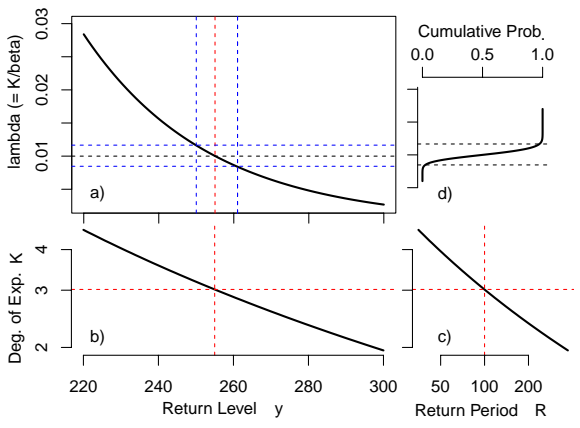

図 -10 ガンマ分布による確率降水量と経験度の算出（再現期間 1 年：左，100 年：右） 


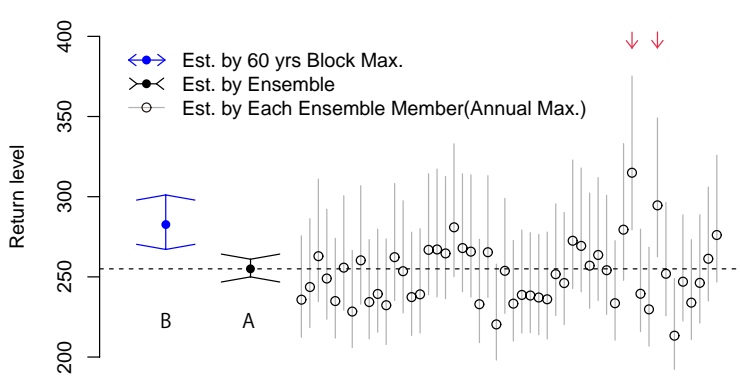

(a) 再現期間 100 年の確率降水量の信頼区間で比較 図-11 アンサンブル毎の推定結果を統合した推定

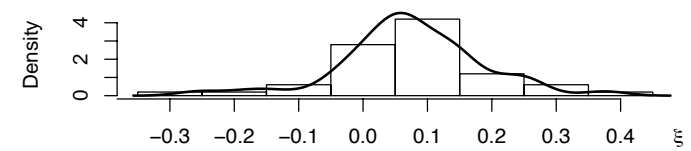

図-12 形状母数 $\xi$ の推定

違の検定（ポアソン検定の拡張）7)によれば，その $p$ 值は $0.0012(\ll 0.01)$ となるので, 生起率の相違は 有意と判断できる。これは, この地点での年最大日 降水量では極值分布への漸近が十分ではないことを 意味し, d4PDF のような多数のアンサンブル標本が ある場合でも，その上位のデータに限定して極值統 計解析をすべきであると言える。なお，図-12 に示 すアンサンブル毎に推定した形状母数 $\xi$ のヒストグ ラムを見ると抢り， $\xi=0$ からわずかに乘離してい る.この乘離が, 有意な相違を招いている可能性も あり, 今後の検討事項である. また, 現実との対応 には, 気象学的なバイアス補正も必要になる.

\section{6.おわりに}

多数のアンサンブル標本を用いることができる状 況での豪雨の頻度解析法について論じた．特に, 煩 雑な統計解析を訝る向きには，2．に記した単純法 が好まれる. 図-2 と図-10に示すと扬，4，で提 案する手法は, その拡張に過ぎない. さらに言えば, 誤差の観点から後者が有利であり，図-9に示す生起 率や 図-11 に示す標本毎の信頼区間について確認で きる点で手厚い解析法であると言える。なお， 60 年 最大值は，各アンサンブル標本にも含まれることか

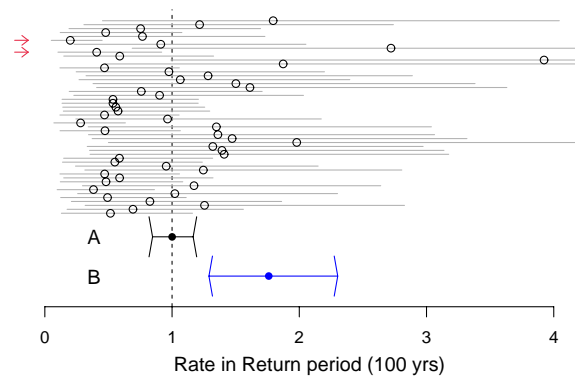

(b) 降雨量 $255 \mathrm{~mm}$ に対する期間 100 年の生起率で比較 (黒) と 60 年最大值から得られる推定の比較（青）

ら, 生起率の相違の検定では, 完全に独立な 2 標本 問題にはなっていない.この問題点の解消はそれほ ど困難ではない，別の機会に紹介する。

謝辞：本研究は科学研究費 (課題番号 25289153 招 よび26420494）ならびに文部科学省委託事業気候変 動リスク情報創生プログラム「課題対応型の精密な 影響評価」のもとで実施された。また，d4PDF の作 成にたずさわった方々，その膨大なデータから必要 なデータを切出していただいた方に謝意を表す.

\section{参考文献}

1) Barolsky, P.: Michelangelo and the power of the imagination (ミ ケランジェロの想像と創造), Michelangelo Buonarroti the making of genius and the 500th ammiversary of the Sistine capel（ミケランジェロ展図録), pp.24-30, 203-205, 2013.

2) 地球温暖化対策に資するアンサンブル気候予測データ ベース (database for Policy Decision making for Future climate change, d4PDF), http://www.miroc-gcm.jp/ pub/ d4PDF/index.html, 2016 年 9 月 30 日閲覧.

3) Coles, S.: An Introduction to statistical modeling of extreme values, Springer, 208p., 2001.

4) 高橋倫也・志村隆彰: 極值統計学, ISM シリーズ : 進化 する数理統計 5, 近代科学社, 262p., 2016.

5) 北野利一・高橋倫也・田中茂信: 確率降雨量の統計解析 におけるモデル適合性の限界，土木学会論文集 B1（水 工学), 第 67 巻, pp.I_277-I_282.

6) 北野利一：伊勢湾台風級の高潮と確率潮位, 第 49 回 水 工学に関する夏期研修会講義集，B-3-1～20, 2013.

7) 北野利一・高橋倫也・田中茂信 : 降水量の極值特性の気 候変動に伴う差異の検出, 土木学会論文集B1(水工学), 第 71 巻, pp. I_361-I_366, 2015.

(2016.9.30 受付)

\title{
COMPREHENSIBLE ESTIMATION OF RETURN LEVELS OF EXTREME PRECIPITATION IN UTILIZING NUMEROUS ENSEMBLE MEMBERS PRODUCED BY CLIMATE MODEL
}

\author{
Toshikazu KITANO, Rinya TAKAHASHI, Shigenobu TANAKA
}

Extrapolation is the essence of extreme value analysis which is applied to the design against the flood risk. In general we face to the obstacle that the finite temporal record length of heavy rainfall is not enough to the reliable estimation, thus as the matter of fact, the applicability of the theories of extreme value statistics to the actual observations of precipitation is uncertain, and we concern there may be discovered another biased story toward the extrapolating region of extreme heavy rainfall. The statistical method is proposed to examine the connection of quantile curves both in our observed record and in the extrapolating region, since the numerous ensembles output by d4PDF are available. The proposed method is demonstrated with an example. 